endorsed the findings of the Drogheda Committee that the Overseas Information Services play an important and essential part in support of British foreign, Commonwealth and Colonial policies; and that the work should be done well, continuously and on an adequate scale. His experience showed that the work being done in the New World met the criteria of quality, continuity and reliability which the Drogheda Committee laid down as essential if Information Services are to exert influence. Dr. King's remarks on the untoward effect of the press campaign which resulted from the report of the Select Committee on Estimates on the Foreign Service was endorsed by other speakers in the debate, and his whole speech was welcomed by Lord John Hope, Joint Under-Secretary of State for Foreign Affairs, who replied for the Government. Lord John Hope said that the Government is fully conscious of the good work being done in the embassies and is doing all that it can to encourage the exchange of teachers and students. He believes that the maintenance of friendly relations between the Englishspeaking peoples of the world is the most important single factor in the maintenance of peace.

\section{Biophysical and Biochemical Cytology}

THe first number of a new journal, Biophysical and Biochemical Cytology, appeared in January, edited by Richard S. Bear, H. Stanley Bennett, Albert L. Lehninger, George E. Palade, Keith R. Porter, Francis O. Schmitt, Franz Schrader and Arnold M. Seligman, and published by the Rockefeller Institute for Medical Research, Baltimore, Md. (published bimonthly, single issues 1.50 dollars, annual subscription 7.50 dollars). From the composition of the editorial board it appears probable that the new journal is intended primarily for the publication of researches carried out in the United States. The intention is "to provide a common medium for the publication of morphological, biophysical and biochemical investigations on cells, their components and their products. It will give special attention to reports on cellular organization at the colloidal and molecular levels and to studies integrating cytological information derived from various technical approaches". The provision of a new journal for publishing work on morphological studies and biophysical studies of cells, with particular emplıasis on electron microscopy, will be a valuable service. It is to be hoped, however, that the more biochemical and cy tochemical investigations will not be published in this joumal, but in the journals which have hitherto made provision for work that is primarily cytochemical or biochemical in nature. The large number of journals that exist already gives rise to some difficulty in keeping in touch with some fields of research, and the primary purpose of journals for the publication of original research should be to bring together material which has a common technical basis.

\section{Greenwich Observations during 1953-54}

Two volumes, for 1953 and 1954 respectively, of the "Observations in Astronomy, Magnetism and Meteorology made at the Royal Observatory, Greenwich" have recently been published (pp. $405+12$ plates, 90 s. net, 1953 ; pp. $270+7$ plates, $70 s$. net, 1954. London: H.M.S.O.). Corresponding issues for $1940,1941,1942,1943$ and 1944 have not yet been published, but those for 1940 and 1941 are expected from the printers very soon. The two volumes under consideration follow the usual plan: section $A$, meridian astronomy, includes work on the transit circle, time service and variation of latitude. Section $B$, equatorial observations, does not appear in the 1954 issue because no equatorial observations were made in that year. Section $C$, photoheliographic observations taken at Greenwich, the Cape and Kodaikanal, includes the daily measures of positions and areas of sunspots and faculæ, general catalogue of groups of sunspots, divided into recurrent groups and non-recurrent groups, total areas of sunspots and faculæ for each day, mean areas of sunspots and faculæ for each rotation and for the year, mean heliographic latitude of spots for each rotation and for the year, and observations of solar flocculi made with the spectrohelioscope. Section $D$, magnetic and meteorological observations, is followed by the report of the Astronomer Royal to the Board of Visitors for each year.

\section{Mydriatic Alkaloids in Excised Root Cultures}

T. M. Strenstra has pointed out that the literature contains few references to the formation of alkaloids in aseptic root cultures, and that the media used have not been entirely synthetic in composition. She now reports the formation of mydriatic alkaloids in excised root cultures of Datura stramonium grown in a completely synthetic medium (Proc. Koninkl. Nederlandse Akad. Wetens., 57, No. 5, Ser. C, 584; 1954). Procedures for obtaining rapidly growing sterile root cultures from seedlings, the composition of the synthetic medium, and methods for extracting and identifying the alkaloids are described. Hyoscyamine appears to be the substance mainly present in the roots. The author reports that, in roots cultured for seventy-seven days, twenty-four times the amount of the alkaloid initially present was synthesized. In an addendum it is noted that the formation of alkaloids in excised root cultures of Datura and Hyoscyamus had already been described by O. F. Uffelie (Pharm. Tijdscr. v. België, 28, 65 ; 1951).

\section{Joint Metallurgical Societies Meeting in Europe}

THE leading metallurgical societies of Belgium, France, Germany, Great Britain and Sweden, together with representatives of the American Institute of Mining and Metallurgical Engineers and the American Society of Metals, will be meeting in Europe during June i-18 to discuss technical and scientific developments in metallurgy and to see something of the various and diverse metallurgical industries in Europe. The proceedings will cover the following topics: iron-making (including coke and ore preparation); steel-making; mechanical working and heat treatment, both ferrous and non-ferrous (including hot and cold rolling, forging, wire-drawing and continuous casting, but not the foundry industry); refining and fabrication of non-ferrous metals; heat treatment; surface treatment (including finishing and coating); metallurgical education and training in industry; and research. The meetings will commence in Great Britain during June 1-7, when the Iron and Steel Institute and the Institute of Metals will be the joint hosts. The dis. cussions will be held in London at Church House, Westminster, and visits will be made to a number of places of technical interest in or near London. In addition, five special tours, each lasting several days, have been arranged for a limited number of members to see one of the following metallurgical areas in Britain : South Wales, Birmingham, Sheffield and 